\title{
The Palestinian Refugees, International Law, and the Peace Process
}

\author{
Robbie Sabel
}

\section{Abstract}

The article reviews recent I srael-Pal estinian negotiations on the issue of the Palestinian refugees. It examines legal aspects of the major issues that were involved in the negotiations including who was responsible for the plight of the refugees, the definition of who is a refugee, the existence of a right of return, and the question of restitution and compensation. The article reaches the conclusion that, in the context of the Arab-Israeli conflict, no legal "right of return" exists, implementation of such a right would beimpracticableand UN General Assembly Resolution 194 does not impose such a right. The article shows, however, that despite deep differences on legal positions, the parties have endeavoured to draft language that will enable them to proceed with a practical solution.

\section{Résumé}

L'article passe en revue les récentes négociations israélopalestiniennes sur la question des réfugiés palestiniens. II examine les aspects légaux des principales questions examinées durant les pourparlers, y compris la question de savoir qui était responsable du problème des réfugiés, la définition de qui est un réfugié, la reconnaissance du droit au retour et la question de restitution et de compensation. L'article conclut que dans le contexte du conflit israéloarabe, il n'existait pas, légalement parlant, de «droit au re tour », quela miseen vigueur d'un tel droit serait pratiquement impossible et quela résolution 194 del'Assemblée générale des Nations U nies n'imposait pas un tel droit. L'article montre cependant que malgré le grand fossé séparant la position légale des deux parties, elles se sont évertuées à utiliser un langage dans les projets de règlement qui laisse la voie ouverte à une solution pratique.
$\mathrm{T}$ he continuing plight of the Pal estinian Arab refugees is a human tragedy that has lasted for more than fifty years and it is clear that without a resolution of the issues involved therecan be no final settlement of the ArabIsraeli conflict.

At the Camp David talks held in July 2000 and in talks held at Taba in January 2001, I sraelis and Pal estinians for the first time attempted to negotiate a solution to the refugee problem. There had been innummerable previous polemic exchanges but here, for the first time, the parties attempted to reach an agreed-upon solution. The negotiations, however, did not reach a successful conclusion. The various reports and accounts of the discussions ${ }^{1}$ show that there were five major areas of disagreement, namely: who was responsible for the plight of the refugees, the definition of who is a refugee, the existence of a right of return, the question of restitution and compensation, and the relevance of the issue of Jews who fled Arab States.

TheArab-I sraeli conflict, although minusculeon aworld scale, nevertheless has captured the attention of world opinion, and the international press follows with fascination theminutiae of the conflict. Thefact that theland is theland of the Bible and the presence of sites holy to Christianity, Islam, and Judaism no doubt are factors in the world's fascination with the issue.

International law continues to play a major role in all attempts to resolve the Arab-I sraeli conflict. This role can be attributed to a number of factors. Both the Arabsand the Jews come from societies based on written legal codes (the Koran and the Bible), and the obligation to comply with legal norms permeates their everyday life. The League of Nations and its successor, the U nited Nations, have been actively involved in Arab-I sraeli affairs in their legal context since the $1923 \mathrm{M}$ andate for Palestine called for the establishment of "a Jewish national home" in Palestine. ${ }^{2}$ Both Israelis and Pal estinians attempt to buttress their respective 
positions by recourse to legal arguments. ${ }^{3}$ World public opinion will not support a position that is regarded asillegal under international law and hence both parties attempt to brand the other side's positions as illegal. Agreement between the parties, if reached, will take the form of binding agreements that will then themselves be subject to the international law of treaties.

Both sides had their international lawyers involved in preparing papers for their negotiators and, in most cases, the lawyers participated in the actual negotiations. An assessment of the legal aspects of the four issues involved is thereforegermane both to examining what went wrong and to possible future solutions.

\section{Responsibility for the Refugee Problem}

During the Camp David and Taba talks, Palestinian negotiators demanded that Israel accept responsibility for the creation of the Arab refugee problem. The Palestinians have stated that it was the issue of East Jerusalem " . . . and I srael's refusal to accept legal and moral responsibility for turning morethan 3 million Pal estinians into refugees that brought the summit to an end." ${ }^{4}$

$H$ undreds of thousands of Palestinian Arabs fled their homes as a result of the 1948 war. Whether these refugees fled as a result of intimidation by Israeli forces, ${ }^{5}$ at the instigation of the invading Arab armies, ${ }^{6}$ or, as is most likely, as a result of a combination of both, there can be no argument as to the human tragedy of this exodus. It does not, however, appear to be equitable or historically correct to place the responsibility with Israel. The root cause of the fighting that caused such tragedy to the Palestinian Arabs and such loss of lives to Israel ${ }^{7}$ was the rejection by the Arab States of the 1947 UN Proposal to partition Palestine into an Arab and a J ewish State. TheA rab States openly declared that they were sending their armiesinto Pal estineto prevent the creation of the proposed Jewish State. ${ }^{8}$ The decision to send in theA rab armies had in fact been madein 1947, prior to the establishment of Israel. ${ }^{9}$ In M ay 1948, the U.S. representativeto the UN Security Council, commenting on the Jordanian admission that the Arab Legion had invaded Pal estine, stated, "W ehaveherethe highest type of evidence of the international violation of the law: the admission by those who are committing the violation." ${ }^{10}$ The Russian representative to the Security Council, Gromyko, stated even more bluntly, "What is happening in Palestine can only be described as a military operation organised by a group of States against the J ewish State."11

The preamble to the only decision ever taken under Chapter VII of the Charter by the UN Security Council in relation to the Arab-Israeli conflict explicitly stated:
Taking into consideration that the Provisional Government of I srael has indicated its acceptance of a prolongation of the truce in Palestine; that the States members of the Arab League have rejected successive appeals of the UN M ediator and of the Security Council in its resolution of 7 July 1948 for the prolongation of thetrucein Palestine; and that there has consequently developed a renewal of hostilities in Pal estine. ${ }^{12}$

M ost telling of all, perhaps, is the 2002 official website of the Arab League, which states, "Among the goals sthe Leagueset for itself were winning independencefor all A rabs still under alien rule, and to prevent the Jewish minority in Palestine (then governed by the British) from creating a Jewish state."13

Prior to the Arab invasion there were no Palestinian Arab refugees. Issa Nakhleh, who was the Permanent Representative of the Arab Higher Committee for Palestine in New York and Chairman of the Palestine Arab delegation, writes:

It is an historic fact that prior to the month of April 1948 Palestine Arabs were winning the fight against the Jews throughout the country, Arabs dominated more than $82 \%$ of thearea of Palestine, Jews were unable to travel on highways between important cities. All Jewish quarters in Jerusalem were about to surrender. Jews lost every battle they fought against Palestine Arabs. $^{14}$

There are presumably two reasons for the Palestinians making such a concerted effort to cause I srael to accept the moral and legal responsibility for thecreation of the refugee problem. The first is to achieve vindication of what the Palestinians feel has been an injustice and the second is to lay the foundations for a subsequent claim for compensation from Israel.

The unofficial understanding reached between Yossi Beilin from Israel and Abu Mazen of the PLO avoids the issue by using language whereby "the Israel side acknowledges the moral and material suffering caused to thePalestinian people as a result of the war of 1947-1949." 15 The Clinton plan uses nearly identical language. ${ }^{16}$

\section{Who Is a Palestinian Refugee?}

The most common estimate is that in 1947-48 some $700,000{ }^{17}$ A rab Palestinians fled their homes. ${ }^{18}$ O ther estimates vary from $400,000^{19}$ to $900,000 .{ }^{20}$ In accordance with the 1967 U N Refugee Convention, a person ceases to be a refugee if "he has acquired a new nationality, and enjoys the protection of the country of his new nationality." 21 If one were to apply this criterion, together with the rule that only persons who actually fled their homes are refugees, then the 
authentic number of refugees today would be some two or three hundred thousand at most. However, due to political pressurefrom Arab States, Palestinians refugees were excluded from the UN Convention definition of refugees and U NRW A granted status of refugeesto all direct descendants of refugees. ${ }^{22}$ It is believed that this extension of refugee status is unprecedented in international law. It has led to a situation wheresome 3,500,000 persons arenow considered Palestinian refugees and Palestinian spokesmen claim that all 3,500,000 have the "right of return." N eedless to say, over 90 per cent of these persons have never lived in the territory that is now Israel.

\section{"Right of Return"}

Palestinian negotiators demand that "I srael must recognize theright of thePalestinian refugees to return to their homes" in what is now Israel in accordance with "a well-established norm in international law and practice, namely the right of return." 23 The existence of such a right under international law in the circumstances of the Arab-Israeli conflict is, however, in dispute. Palestinian demands for a right of return are coupled with their call for self-determination. Dividing historical Palestine into two states, Israel and an Arab State of Palestine, is incompatible with then granting an "inalienable" right to the same Pal estinian A rabs to move to Israel. Benvenisti and Zamir found that "international practice... does not support the claim that the right of return following mass relocation of population is recognized under international law. This observation of state practice is enhanced by the lack of support in legal literature for theright of refugees to return to the country they have fled."24

If such a "right of return" were to exist, it would need to bebased on one of thetwo accepted sources of international law, namely, an international treaty to which Israel is a party or a rule of customary international law. ${ }^{25}$

\section{D oes the "Right of Return" Exist as a Treaty Obligation?}

In the UN treaties that deal specifically with refugees, there is no reference to a "right of return." 26 Israel is a party, however, to two general human rights treaties that refer to a right to return: The Convention on the Elimination of All Forms of Racial Discrimination, ${ }^{27}$ in which Article 5-(d)(ii) refers to "theright to leaveany country, including one'sown, and to return to one's country," and the 1966 International Covenant on Civil and Political Rights, ${ }^{28}$ in which Article 12(4) states: "N o oneshall bearbitrarily deprived of theright to enter his own country."

The question arises as to the meaning of the phrase "one's country" or "his own country" in the two treaties. There are writers who believe the phrases should be understood as applying, in addition to nationals, to perma- nent residents of a country and other persons with ties to the country. State interpretation of a right to re-entry, however, appears overwhelmingly to be applied only to nationals of the State. This is the phrase used in the 1969 A merican Convention on Human Rights, Article 22(5): "No one can be expelled from the territory of the state of which he is a national or be deprived of theright to enter it." ${ }^{29}$ The word "national" is also used in the 1950 European Human RightsConvention, Protocol N 0.4, Article3(2): “No oneshall be deprived of the right to enter the territory of the State of which he is a national." ${ }^{30}$ Apparently no government interprets the Convention as meaning that the right applies to persons other than nationals or persons who were nationals. Guy S. Goodwin-Gill writes, "The'right to return', in particular, is accepted as a normal incident of nationality." 31

\section{Mass or Individual Rights}

The human rights conventions referred to, insofar as they grant rights, do so to individuals and were not intended to deal with population exchanges such as occurred in the Arab-I sraeli conflict. According to Stig Jagerskiold, theright of return or the right to enter one's country in the 1966 International Covenant:

... is intended to apply to individualsasserting an individual right. There was no intention here to address the claims of masses of people who have been displaced as a by-product of war or by political transfers of territory or population, such as the relocation of ethnic Germans from Eastern Europe during and after the Second World W ar, theflight of thePalestiniansfrom what became Israel, or the movement of Jews from the Arab countries. ${ }^{32}$

It is also apparent that the right of return applies to individuals who wish to live as citizens of the State to which they wish to return. It is clearly not realistic to suggest that hundreds of thousands of Palestinian Arab refugees feel such strong ties with Israel that they wish to become loyal Israeli citizens. An Egyptian Foreign M inister explained, "In demanding the return of the Palestinian refugees, the Arabs mean their return as masters, not slaves: or, to put it quite clearly theintention is the extermination of I srael." ${ }^{33}$ Six yearslater, the Prime M inister of Lebanon declared, "The day on which the Arabs' hope for the return of the refugees to Palestine is realized will bethe day of Israel's extermination." ${ }^{34} \mathrm{~A}$ leading Arab Palestinian lawyer put it bluntly when hestated, "The Pal estinian Arab refugees havecertain inalienablerightsincluding the right of sovereignty over Palestine." 35

\section{UN Resolution 194}

Although Arab States voted against UN Resolution 194 (III) of 11 December $1948^{36}$ and although Israel was not a mem- 
ber of the UN at the time the Resolution was adopted, ${ }^{37}$ it is now claimed that the Resolution obliges Israel to recognize a right of return. Paragraph 11 of the Resolution states that the UN General Assembly:

Resolve that the refugees wishing to return to their homes and liveat peace with their neighbours should bepermitted to do so at the earliest practicable date and that compensation should be paid for the property of those choosing not to return and for loss of or damage to property which under principles of international law or in equity, should be made good by the Government or authorities responsible.

Some writers claim, "Paragraph 11 recognized that under international law the Palestinian people were entitled to return to their homeland and receive economic compensation." 38 Further General Assembly Resolutions have repeatedly referred to Resolution 194 and described Palestine refugee rights as "inalienable."

UN General Assembly resolutions cannot, however, cre ate international law. With the exception of resolutions dealing with budget and internal UN affairs, States are not obliged to comply with resolutions of the UN General Assembly. The UN General Assembly is not a law-making body and neither the UN Charter nor any other legal instrument has empowered it with a law-making capacity. ${ }^{39}$ The fact that the UN may repeat or reaffirm a resolution does not empower it with legal force. In Weil's eloquent phrase, "Neither is there any warrant for considering that by dint of repetition, non-normativeresolutionscan betransmuted into positive law through a sort of incantatory effect. ${ }^{40}$

As to the actual text of the Resolution, the word "right" is not used, although Arab spokesmen repeatedly and incorrectly attribute the word "right" to its text. The Resolution uses the word "should" and not "shall." In UN documents the word "should" is regarded as recommendatory language and is not used where an obligation is set out. "The term 'should' is clear on its face: it is hortatory, not obligatory." 41 The referenceto international law is as regards theclauseon compensation and not on theissue of "return." 42

The Beilin-Abu M azen understanding makes no explicit referenceto Resolution 194. The Clinton proposal in regard to the Resolution states: " The parties would agree that this implements Resolution 194."

TheSaudi-initiated Arab League peace plan of $28 \mathrm{M}$ arch 2002 refers to "achievement of a just solution to the Palestinian refugee problem to be agreed upon in accordance with UN General Assembly Resolution 194." ${ }^{43}$ This text, by using the word "agreed," attempts to soften the earlier Arab position that Resolution 194 was mandatory. ${ }^{44}$ W ere I srael to accept the wording of the Arab League proposal, how- ever, it would then be bound to act in accordance with the substance of UN Resolution 194, a demand I srael has rejected for reasons set out above.

\section{The "Right of Return" in Customary International Law}

Some writers, aware of the fact that UN General Assembly Resolutions cannot createinternational law, claim that paragraph 11 of Resolution 194 reflected customary international law at the time. ${ }^{45}$ If a right of return were a rule of customary international law then it would, of course, be binding on Israel, irrespective of Israeli agreement or recognition of the rule.

The existence of a rule of customary international law requires both State practice ${ }^{46}$ and opinio juris ${ }^{47}$ namely, that the State practice was part of a general recognition that a legal obligation is involved. It has been claimed that such a customary rule can be ascertained from the 1948 U niversal Declaration of Human Rights, which states, in Article 13(2): "Everyone has the right to leave any country, including his own, and to return to his country."

The U niversal Declaration is a universally respected statement of ideal sand has inspired much human rights legislation, including legislation in Israel. It is not, however, binding law. Elements of the declaration have indeed been set out in varioushuman rightstreaties and they arebinding on the parties to those treaties. Those elements of the Universal Declaration that have not been incorporated into international treaties remain lofty hortatory call to States; they are not, however, binding international law.

Article 13(2) of the Universal Declaration refers to "his country." Article 21 of the Universal Declaration uses the same phrase and refers to the fact that "everyone has the right to take part in the government of his country."(emphasis added). This is clearly a right attributable only to citizens and since the same phrase is used in Article 13(2), it is logical to deduce that Article 13(2) also refers to citizens. ${ }^{48}$

State experience shows that States have indeed often allowed the return of their citizens who fled during wars. H owever, wherethere has been a division of a territory into two States on an ethnic or religious basis, there has been no such "right of return." The Muslims who fled India for Pakistan have no "right of return" to India, the same being true for $\mathrm{H}$ indus who fled from what is now Pakistan to India. The Sudeten Germans have no "right of return" to the Czech Republic. Julius Stone points out that in fact:

Resettlement . . . has been the effective solution for the far greater and more complex refugee problems in Europe after World War II. It is a melancholy fact that this more humane course came to so little in the M iddle East over so long a time 
that, for the Arab States concerned, the refugee problem was more useful than its solution. ${ }^{49}$

\section{Right of Return in the Post-0slo Peace Process}

In formal presentations, Arab representatives demanded an unconditional right of return. They pointed out, however, that not all refugees would choose to return but insisted that the individual refugee make the choice. During a meeting with President U.S. President Bill Clinton, the Palestinian representative, Nabil Shaat, estimated that 10 to 20 per cent of the refugees would choose to return. President Clinton responded that, according to that estimate, the number of refugees I srael would have to absorb would be between four and eight hundred thousand. ${ }^{50}$

The formula used in the Beilin-Abu Mazen understanding was:

1. Whereas the Palestinian side considers that the right of the Palestinian refugees to return to their homes is enshrined in international law and natural justice, it recognizes that the prerequisites of the new era of peace and coexistence, as well as the realities that have been created on the ground since 1948, have rendered the implementation of this right impracticable. The Palestinian side, thus, declares its readiness to accept and implement policiesand measures that will ensure, insofar asthis is possible, the welfare and well being of these refugees.

2. Whereas the Israeli side acknowledges the moral and material suffering caused to the Palestinian people as a result of the war of 1947-49. It further acknowledges the Palestinian refugees' right of return to the Palestinian state and their right to compensation and rehabilitation for moral and material losses.

3. and 4. (The Articles deal with the establishment of an international fund.)

5. Deals with Israeli willingness to allow family reunification and absorption of refugees in "specially defined cases."

6. Deals with the absorption of refugees in the W est Bank and Gaza Strip.

7. The PLO considers the implementation of the above a full and final settlement of the refugee issue in all its dimensions. It further undertakes that no additional claims or demands arising from this issue will made upon the full implementation of this Framework agreement. ${ }^{51}$

On the question of the refugees, U.S. President Bill Clinton's comments, presented orally to both parties, were:

I sense that the differences are more relating to formulations and less to what will happen on a practical level. I believe that Israel is prepared to acknowledge the moral and material suffe- ring caused to the Palestinian people as a result of the 1948 war and the need to assist the international community in addressing the problem. ... The fundamental gap is on how to handle the concept of theright of return. I know the history of theissue and how hard it will befor the Palestinian leadership to appear to be abandoning the principle.

The Israeli side could not accept any reference to a right of return that would imply arightto immigrateto Israel in defianceof Israel's sovereign policies and admission or that would threaten the character of the state. Any solution must address both needs. The solution will have to beconsistent with the two-state approach. . . thestate of Palestineasthe homeland of thePalestinian peopleand the state of Israel as the homeland of the Jewish people.

Under the two-state solution, the guiding principle should be that the Palestinian State should be the focal point for the Palestinians who choose to return to thearea without ruling out that Israel accept some of these refugees.

I believe that we need to adopt a formulation on the right of return that will makeclear that thereisno specific right of return to I srael itself but that does not negate the aspiration of Palestinian people to return to the area.

I propose two alternatives

1. both sides recognize the right of Palestinian refugees to return to historic Palestine, or

2. both sides recognize the right of Palestinian refugees to return to their homeland.

Theagreement will definetheimplementation of thisgeneral right in a way that is consistent with the two-statesolution. It would list the five possible homes for the refugees:

1. The State of Palestine

2. Areas in Israel being transferred to Pal estine in the land swap

3. Rehabilitation in host country

4. Resettlement in third country

5. Admission to Israel

In listing these options, the agreement will make clear that the return to the West Bank, Gaza Strip and area acquired in the land swap would beright [sic] to all Palestinian refugees, while rehabilitation in host countries, resettlement in third countries and absorption into I srael will depend upon thepolicies of those countries.

Israel could indicate in the agreement that it intends to establish apolicy so that some[sic] therefugeeswould beabsorbed into Israel consistent with Israel sovereign decision.

I believethat priority should begiven to the refugee population in Lebanon.

The parties would agree that thisimplements Resolution $194 .{ }^{52}$ 


\section{Compensation for Abandoned Property of Palestinian Refugees}

The Palestinian Arab refugees left behind, in what is now Israel, large amounts of property. M ost of the property was used by I srael to settle J ews who fled from Arab states. Benvenisti and Zamir point out that this is normal international procedure and that during population transfers in India, Pakistan, and cases in Europe that they enumerate, "immovable property left by expellees was seized by the Governments, which then used it to settle the incoming refugees." 53 They add that in no case of massive relocation "have the refugees regained the property they left behind." 54 There are, however, examples of States paying compensation for such property ${ }^{55}$ and Israeli negotiators have agreed to pay compensation for the property A rab refugees left in what is now Israel. Clearly, so long as a state of war or armed conflict continues, Israel is entitled to freeze the right to such property. However when a final settlement of the conflict is reached, the refugees will be entitled to receive compensation for property they possessed. The terms and conditions for such compensation will have to be agreed upon. Israel also demanded that, when negotiations commence on the question of compensation, account must be taken of the property of Jews who fled Arab countries and who were forced to leave all their property behind.

\section{Compensation for the Suffering of the Refugees}

Above and beyond the right of compensation for property, Palestinian negotiators demand compensation to the refugees for their suffering. Such a demand is linked to the demand that Israel accept responsibility for causing the refugee problem. Sincel sraeli negotiators see the invasion by Arab States as the primary cause of the Palestinian refugee problem, needless to say Israel is not willing to accept responsibility or the consequent obligation to compensate. Benvenisti and Zamir point out, "Claimsfor reparations are rarely pursued. Since such claims are based on fault, the other side must be persuaded to concede its aggression or this issue must be litigated for the claim to succeed." 56

Clearly, neither side in the Arab-I sraeli conflict is willing to see itself as the aggressor. The Beilin-Abu M azen understanding deals with the issue of compensation for the refugees by stating that I srael "acknowledges... their right to compensation and rehabilitation for moral and material losses" and proposing that an international fund be set up to help resettlement of the Palestinian Arab refugees and that Israel participate in such a fund.

\section{Compensation to Jews W ho Fled from Arab Countries}

Some 700,000 Jews fled Arab countries in the years 1948-49. ${ }^{57}$ They have been successfully absorbed by Israel and now form an integral part of the fabric of Israeli society. They do not regard themselves as refugees nor are they regarded as such. N eedless to say there is no talk of their "right to return to Arab countries." On immigrating to Israel they were often forced to leavetheir property behind and in many cases, such as in I raq, special laws were passed depriving them of all rights to their property. I is Israel's position that when discussing issues of compensation, the property rights of the Jews who fled Arab countries be taken into account.

\section{The Issue of Refugees in the Legal Instruments of the Peace Process}

The first agreed framework for a peace settlement was the 1967 UN Security Council Resolution number $242 .{ }^{58}$ The Resolution was not adopted under Chapter VII of the Charter and therefore was not binding as such, but all parties to the conflict have subsequently accepted it as a framework; hence its binding character derives from the agreement of the parties to the conflict. Resolution 242 refers to thenecessity of "achieving a just settlement of the refugee problem." The Resolution makes no referenceto U NGA Resolution 194, or to a "right of return." Furthermore, the Resolution refers to refugees without limiting theterm to Pal estinian refugees, thus enabling the issue of compensation for the property of Jews from Arab countries to come within its ambit.

The 1978 Camp David Framework for Peace in the M iddle East stated: "Egypt and I srael will work with each other and with other agreed parties to establish agreed procedures for a prompt and permanent implementation of the resolution of the refugee problem." 59

The1993 Declaration of Principleson Interim Self Government - theOslo Agreement - reaffirmed UN Security Council Resolution 242 and stated that the issue of refugees should be dealt with as part of "permanent status negotiations." 60

The 1994 T reaty of Peace with Jordan states that theParties will seek to resolve the refugee problem, in accordance with international law, in appropriateforums, including theframework of the M ultilateral Working Group on Refugees, and in negotiations, in aframework to beagreed, bilateral or otherwise, in conjunction with and at the sametime as thepermanent status negotiations pertaining to the Territories that came under Israeli military government in 1967. ${ }^{61}$

The agreements with Egypt, with the PLO, and with Jordan contain no reference to U NGA Resolution 194 or to 
a "right of return." The agreement with the PLO received worldwide support; the Secretary of State of the United States and the Foreign M inister of the Russian Federation signed it as witnesses. The authors of the I srael-PLO agreement shared the $\mathrm{N}$ obel Peace Prize and the agreement was welcomed by a special Resolution of the UN General Assembly. ${ }^{62}$ The 1995 Israeli-Palestinian Interim Agreement on the West Bank and Gaza Strip agreement was signed by representatives of the U nited States, the Russian Federation, Egypt, Jordan, N orway, and the European U nion as witnesses.

A valid argument can be made that, by making these agreements, none of which mentions a "right of return," the PLO and theArab States, with the blessing of the world community, implicitly acknowledged the reality that a "right of return" isnot an option in theArab-Israeli dispute.

\section{The Future}

For some sixty-fiveyears, commencing with the 1937 (Peel) Palestine Royal Commission, the consensus among political and international legal observers has been that historic $\mathrm{Pa}$ lestine needs to be divided into two States, an Arab State and a Jewish State. Such a division is premised on the notion of the right of Palestinians to self-determination in their territory and a similar right for I srael in its territory. The border between two such States needs to be negotiated but, whatever the border, such self-determination is incompatible with a demand for the recognition of a right of Palestinians to settle in I srael. Ruth Lapidoth summarizes the legal position under international law as being that "neither under the general international conventions, nor under the major UN resolutions, nor under the relevant agreements between the parties, do the Palestinian refugees have a right to return to Israel." 63

Thirty years ago William Fulbright commented, "For the majority of refugees, repatriation would probably be neither feasible nor desired." 64 In January 2001, President Clinton declared that Israel should absorb some refugees but that ". . . you cannot expect I srael to acknowledge an unlimited right of return to present day Israel. . . . We cannot expect Israel to make a decision that would threaten the very foundations of the State of I srael and would undermine the whole logic of peace." 65

Some one million of the Arab refugees who claim a right of return reside, at present, in the West Bank and Gaza. Their claim therefore is not to have a right of return to what was historically Palestine, for they arealready live there, but to that part of Palestine that is present-day Israel.

TheBeilin-Abu M azen understanding is premised on the reality that a right of return will beto a Palestinian State and not to Israel. The understanding states that although the Palestinians believe "that the right of the Palestinian refu- gees to return to their homes is enshrined in international law and natural justice... . the realities that have been created on the ground since 1948, haverendered theimplementation of this right impracticable." I srael "acknowledges the Palestinian refugees' right of return to the Palestinian Stateand their right to compensation and rehabilitation for moral and material losses." ${ }^{66}$ Allowing refugees in camps in Arab countries to "return" to a Palestinian State in the West Bank and Gaza would be allowing their return to what historically was Palestine. In 2001 the chief U.S. negotiator for the M iddle East pithily summarized the issue: "The right of return of Palestinians to their State makes perfect sense, the right of return to Israel made no sense if you are going to have a two-state solution." ${ }^{67}$

Echoes of the Beilin-Abu Mazen understanding are found in President Clinton's peace plan where he refers to "the right of return to their homeland where it is clearly established that their homeland means the Palestinian State." ${ }^{68}$ At the September 2000 Taba talks between Israel and the Palestinians the refugee problem was perhaps the major issue. The Israeli proposal during the Taba talks ${ }^{69}$ again echoed the Beilin-Abu M azen understanding that the Palestinians would have the right of return to the future Palestinian State together with the further options of being absorbed in the host states or immigrating to third states willing to absorb them. A further proposal was that Israel would agree to accept an as-yet-unarticulated number of refugees on the humanitarian basis of family reunification. An international fund would be set up to help cover the cost of resettlement and rehabilitation. The final settlement would be considered as implementation of all relevant international resolutions. A settlement of claims would also deal with the question of the property of Jews who fled Arab countries.

It has been said that the saddest phrase in the English language is "if only." This year Israel cel ebrates fifty-five years of independence. For many Palestinians, however, this year means fifty-five years since the creation of the refugee problem. It need not have been so. With wise Arab leadership at the time, it could now have been fifty-five years of independence for both Israelis and Palestinians. The Beilin-Abu Mazen "understanding" and the Clinton "comments" could well be a blueprint for a practical, pragmatic solution to the Palestinian refugee problem. It is to be hoped that, this time, a Palestinian leadership will grasp the opportunity and not, as has occurred so often in the past, discard it in the chimeric hope that a deus ex machina will somehow turn back the clock of history.

\section{Notes}

1. On the most recent Israeli-Palestinian attempts to reach a solution, see "The Refugee Problem at Taba, Akiva Eldar 
Interviews Yossi Beilin and Nabil Sha'ath" (2002) 9:2 Palestine-Israel Journal of Politics Economics and Culture: Right of Return 12;A. Hanieh, TheC amp David Papers, online: <http:// www.nad-plo.org/eye/cdpapers.pdf > (date accessed: 17 November 2002); G. Sher, Just Beyond Reach, The Israeli-Palestinian Peace N egotiations 1999-2001 (Tel Aviv: M iskal-Yedioth Ahronoth Booksand Chemed Books 2001; in H ebrew); Camp David Summary, 26 July 2000, Palestine Liberation Organization, Negotiations Affairs Department (26 July 2000), online: $<$ <ttp://www.nad-plo.org/david/ cdsu16.html> (date accessed: 17 N ovember 2002); B. Aluf, "US Proposal Aims to Please Both Sides" $\mathrm{H}$ a'aretz D aily N ewspaper, Engli sh Internet Edition (28 December 2000), online: <http://www.haaretz. co.il> (dateaccessed: 23 N ovember 2002); R. M alley, "Correct These Fictions about the Failure at Camp David" International Herald Tribune(9July 2001), online: <http://www.iht.com/iht search.php?id=25444\& owner $=\&$ date $=20010709000000>$ (date accessed: 21 November 2002); U.S. President Bill Clinton's speech on Middle East peace (Israel Policy Forum, N ew York, 7J anuary 2001), online: <http://www.usembassy-israel. org.il > (dateaccessed: 18 N ovember 2002); A mbassador Dennis Ross, Former Special M iddle East Coordinator, "Pursuing Peace: Inroads M ade and Lessons Learned" (address given at Georgetown University Law Center, Washington, D.C., 19 July 2001), online: <http:// www.mideastinsight.org/7_01/ policyforum.html> (date accessed: 17 November 2002); "A Look at the Beilin-Abu Mazen Agreement," Ha'aretz Daily Newpaper, English Internet Edition (31 October 1995), online: <http://www. haaretz.co.il>(dateaccessed: 23September 2000);Y. Beilin, Manual For a Wounded Dove (Tel Aviv: Miskal-Yedioth Ahronoth Books and Chemed Books, 2001; in Hebrew).

2. Article 2 of the British $M$ andate for Palestine, confirmed by the Council of the League of Nations, 24 July 1922, League of Nations O fficial Journal, August 1922, p. 1007.

3. For recent legal analyses, see G.J. Boling, The 1948 Palestinian Refugees and the Individual Right of Return, An International Law Analysis (Bethlehem: Badil Resources Center for Palestinian Residency and Refugee Rights, 2002), online: <http://www.badil.org/publications/legal papers/RoR48.pdf> (date accessed: 19 N ovember 2002); T. Kramer, "The Controversy of a Palestinian 'Right of Return' to Israel" (2000) 18 Arizona Journal of International and Comparative Law 979; R. Lapidoth, "Legal Aspects of thePalestinian Refugee Q uestion" (2002) 485 Jerusalem Viewpoints, Jerusalem Center for Public Affairs, online: <www.jcpa.org/jl/ vp485.htm> (dateaccessed: 20 October 2002).

4. Camp David Summary, supra note 1.

5. B. M orris, TheBirth of thePalestineR efugee Problem 1947- 1949 (Cambridge: CambridgeU niversity Press, 1987). It is relevant to point out that M orris, in his book, which is highly critical of the behaviour of thel sraeli army in 1948, nevertheless states that the Israeli army did not, as a rule, take any action to encourage refugees to fleefrom villages unlessthevillagers had actually participated in the fighting.
6. The London weekly Economist reported on October 2, 1948: "Of the 62,000 Arabs who formerly lived in Haifa not more than 5,000 or 6,000 remained. Various factorsinfluenced their decision to seek safety in flight. There is but little doubt that the most potent of the factors were the announcements made over theair by the Higher Arab Executive, urging the Arabs to quit. ... It was clearly intimated that those Arabs who remained in $\mathrm{H}$ aifa and accepted Jewish protection would be regarded as renegades." Emil Ghoury, Secretary of the(Pal estinian) A rab Higher Committee, stated: "The fact that there are those refugees is the direct consequence of the Arab States in opposing partition and the] ewish state" ([London] Daily Telegraph, 6 September 1948).

7. Approximately 6000 Israelis were killed in the 1948 war. The total Jewish population of Palestine at the time was some 600,000

8. See cable of 15 May 1948 from the Secretary General of the League of Arab States to the Secretary General of the UN, UN SCOR, Supp., M ay 1948, p. 83, UN Doc. S/745 (1948).

9. B.Y. Boutros-Ghali, The Arab League, International Conciliation, N o. 498 (New York: Carnegie Endowment for International Peace, 1954) 411.

10. UN Security Council Official Records, No. $72,302^{\text {nd }}$ meeting, p. 43 (1948).

11. UN Security Council Official Records, $309^{\text {th }}$ meeting (1948).

12. UN Security Council Resolution N o. 54, of 15 July 1948, UN Document S/902 (1948).

13. Online: <http://www.arabji.com/ArabGovt/ArabLeague.htm> (date accessed: 23 November 2002). The parenthesis is in the original text.

14. I. Nakhleh, "The Liberation of Palestine Is Supported by International Law and Justice" in J.N. Moore, ed., The Arab-Israeli Conflict, vol I: Readings, sponsored by the American Society of International Law (Princeton, N .J.: Princeton U niversity Press, 1974) 570.

15. The text is from Annex 1 to $Y$. Beilin, supra note 1, English from "A Look at the Beilin-Abu Mazen Agreement," supra note 1.T he text was never officially acknowledged by the Palestinians as even constituting an understanding.

16. "M inutes of U.S. President Bill Clinton's comments at a meeting with Israeli and Palestinian representatives at the White house on December 23, 2000, as given to $\mathrm{H}$ a'aretz by Palestinian sources," online: $\mathrm{Ha}$ a'aretz O nline, Archives <http:// www. haaretzdaily.com/arch/objects/data/logonEng. jhtml> (date accessed: 23 N ovember 2002).

17. G.J. Tomeh, "Legal Status of Arab Refugees", in J.N. M oore, ed., supra note 14,670 .

18. This paper discusses the issue of the refugees from the 1948 war. The issue of persons displaced from the W est Bank in the 1967 war has proven to be less contentious as the Palestinians will befree to admit them back to theW est Bank when thefinal status of the W est Bank is agreed upon.

19. J.E. Katz, Arab Refugees, and the "Right of Return," online: <http://www.eretzyisroel.org/ samuel/refugees.html> (date accessed: 17 N ovember 2002). 
20. Final Report of the U nited N ationsEconomic Survey M ission for the M iddle East, UN Publications 28, December 1949, Part I, p. 18.

21. Article $1(C)(3)$ Convention Relating to the Status of Refugees 1951, entered into force 22 April 1954, 189 UNTS 150.

22. See G.S. Goodwin-Gill, The Refugee in International Law, $2^{\text {nd }}$ ed. (Oxford and N ew York: Oxford U niversity Press, 1998) 220.

23. Refugees, Background, Palestine Liberation Organization, $\mathrm{Ne}$ gotiations Affairs Department, Permanent Status I ssues, online: <http://www.nad-plo.org/permanent/refugees.html> (date accessed: 18 N ovember 2002).

24. E. Benvenisti and E. Zamir, "PrivateClaimsto Property Rightsin theFuturel sraeli-Palestinian Settlement" (1995) 89:295AJIL 325.

25. These sources of international law, together with "the general principles of law recognized by civilized nations," to beapplied by the ICJ, are set out in Article 38 (1) of the Statute of the International Court of Justice.

26. Convention Relating to the Status of R efugees 1951, entered into force 22 April 1954, 189 UNTS 150; Protocol Relating to the Status of Refugees, 1967, entered into force 40 ctober 1967, 606 UNTS 267. Israel is a Party both to the Convention and to the Protocol.

27. Convention for the Elimination of All Forms of Racial Discrimination 1965, entered into force4 January 1969, 660 U NTS 195. Israel is a Party.

28. International Convention on Civil and Political Rights 1966, entered into force23M arch 1976, 999 U NTS171. Israel isa Party.

29. American Convention on Human Rights 1969, entered into force 18 July 1978, 9 ILM 673 (1970).

30. European Convention for the Protection of Human Rights and Fundamental Freedoms 1950, entered into force 3 September 1953, 213 UN TS221; Protocol N 0.4 to theEuropean Convention for theProtection of H uman Rights and Fundamental Freedoms, 1963, entered into force 2 M ay 1968, ETS 46. Israel is a Party to neither the Treaty nor the Protocol.

31. G.S. Goodwin-Gill, supra note 22, 16; see G.S. Goodwin-Gill, "Comments on: The Right to Leave, The Right of Return and the Question of a Right to Remain," in V. Gowlland-Debbas, ed., The Problem of the Refugees in Light of Contemporary International law I ssues (The Hague: M artinus Nijhoff, 1996) 101. That the right of return is restricted to nationals is also reflected in the "Declaration of Principles of I nternational Law on M ass Expulsion" (1986) 62:13 International Law Association Conference Report (ILA), Articles 1,2,3,7.

32. S. Jagerskiold, "The Freedom of Movement", in L. Henkin, ed., The International Bill of Rights (New York: Columbia University Press, 1981) 180.

33. Egyptian Foreign M inister, Salah-el-Din, The Egyptian daily newspaper Al-M isri, Cairo (11 O ctober 1949), quoted from N. Feinberg, Studies in International Law, with a Special Reference to theArab-I srael Conflict (J erusalem: Hebrew U niversity, M agnes Press, 1979) 506.

34. Abdullah el-Yafi, Prime M inister of Lebanon, the Lebanese dailynewspaper El-H ayat, Beirut (29 A pril 1966), quoted from Feinberg, ibid.
35. G.J.Tomeh, "Legal Status of Arab Refugees" in J.N. M oore, ed., supra note 14

36. GAOR, $3^{\text {rd }}$ session, part I, 1948, Resolutions, pp. 21-24.

37. Some Arab spokesmen claim that Israel's acceptance as a member of the United $\mathrm{N}$ ations was conditional on acceptance of UNGA Resolution 194 and that Israel did indeed agree to abide by all UN General Assembly Resolutionswhen it applied for membership. The UN Charter does not, however, make any provisionsfor such conditional membership and I srael did not makeany unconditional assurance. I nis Claudecomments on this issue: "The best evidence that I srael had made no such commitments was provided by the speeches of Arab delegates in the plenary meeting at which the resolution was voted; they regarded theadmission of I srael as arepudiation of their demand for capitulation on the repatriation issueby theapplicant state, and they asserted with bitterness that Israel "had given no definite assurances';" see I.L. Claude Jr., National M inorities, An International Problem (Cambridge, M ass.: H arvard U niversity Press, 1955) 181. See also N. Feinberg, supra note 33, 438.

38. M.S. Bassiouni and E.M. Fisher, "The Arab-I sraeli Conflict Real and Apparent Issues: An Insight into Its Future from the Lessons of the Past" in J.N. M oore, ed., supra note 14, 645.

39. See K. Skubiszewski, "The Elaboration of General Multilateral Conventions and of Non-Contractual Instruments Having a Normative Function or Objective, Resolutions of the General Assembly of the United Nations, Definitive Report and Draft Resolution" 61 Yearbook of the Institute of International Law [1984 I] 311.

40. P. W eil, "Towards RelativeN ormativity in International Law" (1983) 77:413 AJIL 417.

41. G.R. Watson, The O slo Accords. International Law and the Israel-Palestinian Peace Agreements (Oxford and New York: Oxford University Press, 2000) 282.

42. See R. Lapidoth, supra note 4.

43. Arab League, Arab Gateway, Arab Peace Initiative, 2002, online: <http://www.al-bab.com/arab/docs/league/peace02. htm> (date accessed: 20 N ovember 2002).

44. An earlier draft of the plan called for the solution to be "in conformity with UN General Assembly Resolution 194;" ibid.

45. See for example G.J. Boling, supra note 3, 10.

46. "The practice of states; that is to say, we must look at what states do in their relations with one another." J.L. Brierly, The Law of Nations, $6^{\text {th }}$ ed. (Oxford: Oxford U niversity Press, 1963) p. 59.

47. Defined in James Fox, Dictionary of International and Comparative Law (Ocana Publications, 1992) as "opinion that an act is necessary by rule of law."

48. See R. Lapidoth, "The Right of Return in International Law," Background Paper No. 10 (in H ebrew) (Jerusalem: Jerusalem Institute for Israel Studies, 1993) 3.

49. J. Stone, Israel and Palestine, Assault on the Law of Nations (Baltimore and London: The John H opkins University Press, 1981) 68

50. G. Sher, supra note 1, 216.

51. Supra note 15.

52. Supra note 16 
53. E. Benvenisti and E. Zamir, supra note 24.

54. Ibid. at 324.

55. See examples in S.P. Ladas, TheExchange of M inorities: Bulgaria, Greece and Turkey (New York: M acmillan, 1932).

56. Supra note 16 at 319.

57. See generally M.M. Roumani, The Case of the Jews from Arab Countries: A N eglected Issue (Tel Aviv: World Organization of Jews from Arab Countries, 1983).

58. SCOR, $22^{\text {nd }}$ year, Resolutions and Decisions, 1967, p. 5.

59. 1138 UNTS 39 (1978). ArticleA, 4.

60. 32ILM 1525 (1993), ArticleV (2) (3). A similar clauseappears in the 1995 I sraeli-Palestinian Interim Agreement on theW est Bank and Gaza Strip, 36 ILM 551 (1997) (extract) full text in 33 Kitvei Amana No. 1071 pp. 1-400. (Official Israel Treaty Series).

61. 34 ILM 43 (1995). Articles 3, 8 (b)(c). The text quoted is a composite text from the Articles referred to.

62. UN General Assembly Resolution A/RES/48/58 (1993).

63. R. Lapidoth, "Israel and the Palestinians: Some Legal Issues" DieF riedens-Warte, J ournal of I nternational Peaceand O rganization, (2001) Band 76, H eft 2-3, 211, 238.

64. J.W. Fulbright, "Old M yths and New Realities II: The M iddle East" in J.N. Moore, ed., The Arab-Israeli Conflict, vol. 2: Readings, sponsored by the American Society of I nternational Law (Princeton, N .J.: Princeton University Press, 1974) 1062.

65. U.S. President Bill Clinton's speech on Middle East peace at the Israel Policy Forum in N ew York, supra note 1.

66. "A look at the Beilin-Abu M azen agreement," supra note 1.

67. Ambassador Dennis Ross, supra note 1.

68. B. Aluf, supra note 1. The article states that it is based on notes taken by Israel Foreign M inister Ben-Ami of the President's proposal.

69. Supra note 50 at 430 .

Dr. Robbie Sabel, the former Legal Adviser to the Israel M inistry of Foreign Affairs, teaches international law at the $\mathrm{He}$ brew University, Jerusalem. His book, Procedure at International Conferences (Cambridge University Press, 1997) was awarded the Annual Award by the American Society of International Law. 